\title{
Perkembangan Riset Penerapan Analytical Hierarchy Process Pada Decision Support Systems dan Dampak Penggunaanya di Indonesia
}

\author{
I Putu Agus Priska Suryana ${ }^{1}$, Nyoman Pramaita ${ }^{2}$, Made Sudarma ${ }^{3}$ \\ [Submission: 05-05-2021, Accepted: 08-08-2021]
}

\begin{abstract}
The company ability to manage employees is one of the success factors of the company. In management, it is inseparable from employee performance appraisal because employees are important assets of the company. In this case the decision support system can support decision making to solve unstructured and complex cases. In its application the decision support system uses the Analytical Hierarchy Process (AHP) method. AHP can solve complex cases where quite a lot of criteria are taken. In addition to the use of a decision support system, the effect of its application on employees in an institution also needs to be analyzed. Analysis of the effect using Multiple Linear Regression. Multiple Linear Regression is used to determine the effect of 2 or more independent variables on the dependent variable. This study aims to determine how the application of the AHP method in ranking workers in an organization and analysis of the effect of its application on employee motivation. From several research reviews in Indonesia, it was found that some applied the Analytical Hierarchy Process (AHP) method to assist in the decision support process. These institutions/organizations are engaged in Academic, Private, Hospital, Tourism, and Government sectors. This study found the results of the evaluation of the development of the desktop-based AHP system being the most dominant with $58 \%$ where in government projects the most was $48 \%$.
\end{abstract}

Keywords-Decision Support System, Analytical Hierarchy Process, AHP, Information System, Multiple linear regression

\begin{abstract}
Intisari-Kemampuan perusahaan memanajemen pekerja merupakan salah satu faktor keberhasilan perusahaan. Dalam memanajemen, tak terlepas dari penilaian kinerja kariawan karena kariawan aset penting perusahaan. Dalam hal ini sistem pendukung keputusan dapat mendukung dalam pengambilan keputusan untuk memecahkan kasus-kasus tidak terstruktur dan kompleks. Pada penerapannya Sistem pendukung keputusan menggunakan metode Analytical Hierarchy Process (AHP). AHP berguna untuk pemecahan kasus kompleks karena kriteria yang diambil cukup banyak. Selain penggunaan sistem pendukung keputusan, pengaruh penerapannya terhadap kariawan pada suatu lembaga juga perlu di analisis. Analisis pengaruhnya menggunakan Multiple Linear Regression. Multiple Linear Regression berguna dalam mencari pengaruh 2 atau lebih variabel bebas terhadap variabel terikat. Penelitian ini bertujuan untuk
\end{abstract}

${ }^{1}$ Mahasiswa, Program Studi Magister Teknik Elektro, Fakultas Teknik Universitas Udayana, Jln. P.B. Sudirman, Denpasar-Bali Kode Pos : 80232.(tlp/fax: 081999597582; e-mail:I aguspriska suryana@gmail.com)

2, ${ }^{3}$ Dosen, Program Studi Magister Teknik Elektro, Fakultas Teknik Universitas Udayana, Jln. P.B. Sudirman, Denpasar-Bali Kode Pos : 80232.(tlp/fax:0361-239599; e-mail:2pramaita@ee. unud.ac.id, ${ }^{3}$ msudarma@unud.ac.id)

Agus Priska: Perkembangan riset penggunaan metode AHP ... mengetahui bagaimana penerapan dari metode AHP dalam merangking pekerja pada suatu organisasi serta analisis pengaruh penerapanya terhadap motivasi pekerja. Dari beberapa review penelitian yang ada di Indonesia ditemukan beberapa yang menerapkan metode Analytical Hierarchy Process (AHP) untuk membantu dalam proses pendukung keputusan. Lembaga/ organisasi tersebut bergerak, dibidang Akademik, Swasta, Rumah Sakit, Pariwisata, dan Pemerintah. Penelitian ini mendapatkan hasil evaluasi pengembangan sistem AHP berbasis dekstop menjadi paling dominan dengan angka $58 \%$ dimana pada project pemerintahan menjadi yang terbanyak $48 \%$.

Kata Kunci-Sistem Pendukung Keputusan, Analytical Hierarchy Process, AHP, Sistem Informasi, Linear Regresi Berganda

\section{PENDAHULUAN}

Perkembangan dunia teknologi informasi yang begitu pesat beberapa dekade ini tentu saja telah banyak mempengaruhi berbagai sektor, salah satunya disektor pengelolaan sumber daya manusia. Kemampuan perusahaan dalam memanajemen pekerjanya menentukan keberhasilan perusahaan. Beberapa faktor penting yang dapat menentukan kesuksesan perusahaan adalah manajemen kinerja pekerja yang bekerja sama dengan perusahaan. Karyawan merupakan aset penting dalam perusahaan oleh karena itu perusahaan sekiranya wajib melakukan penilaian kinerja karyawan untuk mengukur kontribusinya terhadap perusahaan secara periodic. Memiliki karyawan yang bagus baik dalam hal attitude, kemampuan, dan komunikasi akan memberikan kontribusi yang positif untuk perusahaan. Dalam memanajemen suatu perusahaan tentunya dibutuhkan teknologi informasi yang baik. Teknologi ini berprinsip untuk melayani kebutuhan informasi secara tepat guna, tepat waktu, dan tepat sasaran [1]. Penggunaan teknologi informasi akan meningkatkan kinerja perusahaan apabila didukung dengan kemampuan dalam memakai komputer [2].

Pengambilan sebuah keputusan dapat dikatakan hasil dari progress kognitif dimana akan diarahkan dalam pemilihan suatu arahan dalam tindakan pada beberapa pilihan yang ada. Dalam suatu proses pengambilan sebuah keputusan akan menuju pada satu pilihan final. Hasil akhirnya bisa berbentuk sebuah tindakan ataupun sebuah opini terhadap suatu pilihan. Menurut ahli, Brinckloe: Pengambilan sebuah keputusan merupakan proses dalam pemilihan menggunakan metode yang efisien sesuai situasi [3]. Proses tersebut untuk menyelesaikan masalah organisasi. Decision Support Systems (DSS) atau mudahnya Sistem Pendukung Keputusan (SPK) adalah sistem yang membantu saat menyelesaikan kasus permasalahan maupun keahlian dalam pengkomunikasian untuk kasus dengan keadaan tidak terstruktur maupun semi terstruktur, kondisi saat tak satu orang pun mengetahui dengan pasti

$$
\text { p-ISSN:1693 - 2951; e-ISSN: 2503-2372 }
$$


bagaimana cara meraih sebuah keputusan [4]. AHP merupakan metode pengambilan sebuah keputusan. AHP dapat membantu saat pengambilan sebuah putusan secara efektif dari suatu persoalan kompleks dengan mempersingkat dalam proses mencari keputusan serta memecahkan persoalan kasus persoalan tersebut ke tiap bidangnya, lalu menata setiap variable lalu mensintesis berbagai pertimbangan agar dapat memberi pengaruh terhadap hasil pada keadaan tersebut. AHP nantinya membantu saat pemberian layaknya nilai standar dengan mengisi bobot kriteria dimana nantinya bobot tersebut yang digunakan dalam menilai pekerja yang direkomendasi kontrak kerja nantinya. Penentuan nilai bobot ini nantinya akan diambil dari beberapa paramter yang tercatat harian pada sistem oleh pekerja. Dalam analisis pengaruh, akan berfokus pada pengaruh implementasi dari sistem dan keterbukaan terkait transparansi nilai kinerja terhadap motivasi kerja kariawan. Pada tahap ini peneliti menerapkan metode Analisis Regresi Linier Berganda, dimana metode ini berguna dalam mengetahui bagaimana pengaruh variabel independen (Sistem SPK dan keterbukaan nilai kinerja) terhadap varibel dependent (Motivasi Kerja).

Artikel ini mencoba menelaah perkembangan penelitian Analytical Hierarchy Process (AHP) khususnya penelitian yang mengambil obyek yang berlokasi di Indonesia. Tujuan artikel ini adalah untuk mengetahui perkembangan Decision Support Systems dengan metode Analytical Hierarchy Process (AHP) serta analisis dampak implementasinya dengan metode Multiple Linear Regression di Indonesia, lembaga/instansi yang telah menjadi obyek pengembangan DSS, problem yang dihadapi dalam pengembangannya, dan solusi yang direkomendasikan oleh peneliti di Indonesia. Informasi ini diharapkan dapat memberi gambaran cepat tentang perkembangan Analytical Hierarchy Process (AHP) di Indonesia bagi lembaga negeri/swasta yang berkeinginan membangun Decision Support Systems.

\section{KAJIAN PUSTAKA}

\section{A. Decision Support System}

Konsep Decision Support Systems (DSS) dimana sistem ini berbasis komputer dan interaktif yang membantu persingkat pengambilan sebuah keputusan. DSS merupakan sebuah sistem yang bisa membantu menyelesaikan kasus permasalahan ataupun pengkomunikasian dalam masalah semi terstruktur maupun tidak terstruktur [5]. Informasi akhir akan dimunculkan dalam bentuk laporan periodik, serta keluaran model matematika sebuah sistem pakar. Di beberapa permaslahan, sistem informasi cenderung gagal memberi keputusan yang khusus guna pemecahan satu permasalahan cukup spesifik. Dalam hal SPK-lah yang diharapkan untuk memenuhi kebutuhan ini. SPK bertujuan sebagai penyedia informasi, memberikan perkiraan, membimbing, serta memberi jalan kepada pengguna informasi agar mampu dalam mengambil keputusan secara bijak. SPK adalah implementasi teori-teori decision making dikemukakan oleh ilmu pengetahuan seperti operation research serta management science, dimana saat dulu dalam pencarian problem solving harus dilaksanakan sebuah perhitungan iterasi dimana itu dilakukan secara manual agar menemukan nilai maksimum, minimum, atau optimum, sedangkan sekarang computer sudah dapat menawarkan kemampuannya dalam menyelesaikan masalah yang serupa dengan waktu yang lebih singkat. Sprague dan Watson mengartikan SPK sebagai sistem yang punya lima karakteristik penting yaitu: Sistem yang dapat membantu para decision making, simulasi yang interaktif, data dan model analisis adalah komponen penting, sistem dengan basis computer, mampu memecahkan masalah yang memiliki karakter sulit dan mustahil dipecahkan dengan kalkulasi manual [6].

Secara umum SPK dibangun dengan tiga komponen utama yaitu Model Base, database Management, dan Software System/User Interface. Hal tersebut dapat diperlihatkan seperti gambar di berikut ini.

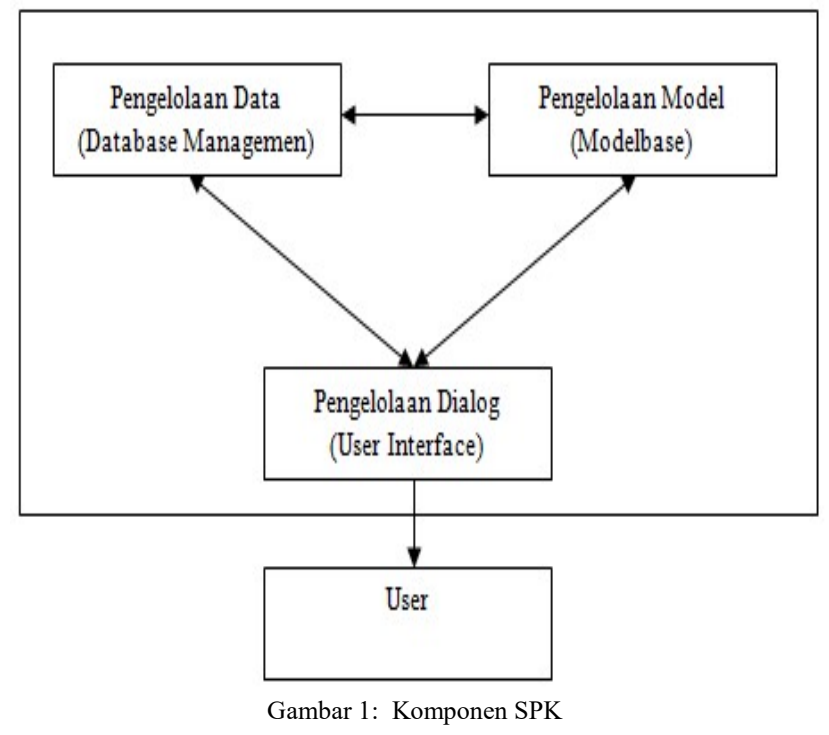

Perintis Sistem Pendukung Keputusan lain seperti Peter G. W. Keen beserta Scott Morton mendefinisikan tiga target tujuan wajib SPK. Ini mengacu pada prinsip dasar SPK dimana hal tersebut terdiri dari tiga yaitu dukungan keputusan, problem structure, dan efektivitas suatu keputusan. Tiga target tersebut adalah yang pertama DSS harus mampu membantu pimpinan ketika menentukan sebuah keputusan dalam pemecahan kasus semi-terstruktur, yang kedua dalam melakukan penilaian bukan untuk menggantikannya, serta ketiga meningkatkan kemampuan efektifitas manajer dalam pengambilan sebuah keputusan daripada efisiensinya [7].

\section{B. Metode Analytical Hierarchy Process}

Professor Thomas L. Saaty adalah pengembang metode AHP pada tahun 1970, dalam menuntaskan masalah komplek saat data beserta informasi secara statistik dari masalah seperti itu sangatlah sedikit [8]. Cara kerja AHP adalah adanya hirarki fungsional dimana dasar utamanya merupakan persepsi manusia. nantinya, permasalahan yang tidak terstruktur akan dipecah-pecah menjadi beberpa bagian dimana nantinya akan dimasukkan ke tiap kelompoknya kemudian disusun ke dalam bentuk hirarki. Metode AHP efektif dalam mengambil keputusan multi kriteria beserta multi alternatif . 


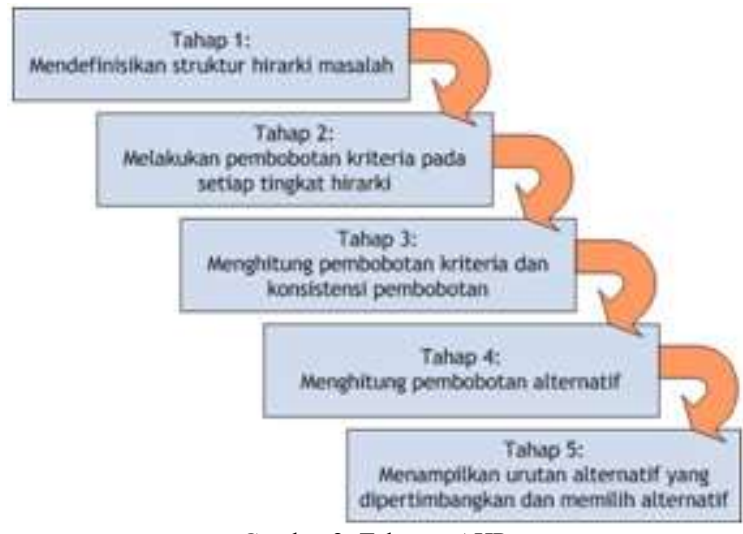

Gambar 2: Tahapan AHP

AHP berguna saat pemecahan kasus kompleks dimana menyusun sebuah hirarki kriteria, yang dinilai secara subjektif dari kelompok yang berkeperluan dan mengambil berbagai kemungkianan agar dapat membangun bobot prioritas. Ketika menyelesaikan suatu masalah dengan AHP berikut prinsip prinsip dasar yang wajib dimengerti, seperti halnya : Penyusunan hirarki yang dimana penentuan targetlah yang menjadi sasaran sistem keseluruhnya pada level tertinggi. Lalu ada penilaian kriteria serta alternative yang dilakukan menggunakan perbandingan dalam berpasangan. Dimana skala satu hingga sembilan skala terbaik dalam menggambarkan ataupun mengekspresikan opini. Tabel analisis digunakan untuk menghitung Nilai dan definisi pendapat kualitatif. Kemudian ada penentuan prioritas pada tiap alternatif dan kriteria, maka dibandingkan secara berpasangan atau dalam bahasa asing pairwise comparisons. Tiap nilai hasil perbandingan yang relatif dari alternatif kriteria dapat disesuaikan sesuai judgement agar dapat menghasilkan sebuah bobot serta prioritas. Matrix dapat menghitung Bobot dan prioritas melalui penyelesaian persamaan matematika.

\section{Metode Multiple Linear Regression}

Analisis regresi linier berganda dapat diartikan sebagai hubungan secara linear antara dua atau lebih variabel independen (X1, X2,...Xn) dengan variabel dependen (Y). maka data yang digunakan biasanya berskala interval atau rasio. Berikut Persamaan regresi linear berganda :

$$
\begin{aligned}
& Y=\alpha+\beta \mathbf{1 X 1}+\beta \mathbf{2 X} \mathbf{2}+\cdots . .+\beta \boldsymbol{n} \boldsymbol{X n}+\boldsymbol{e} \\
& Y=\text { Variabel dependen (nilai yang diprediksikan). } \\
& X=\text { Variabel independen. } \\
& \alpha=\text { Konstanta (nilai Y' apabila } X 1, X 2 \ldots . X n=0 \text { ) } \\
& \beta=\text { Koefisien regresi }
\end{aligned}
$$

Regresi linear memiliki syarat syarat dapat dikatakan asumsi klasik dimana syarat tersebut wajib dipenuhi agar menghasilkan sebuah model prediksi bersifat Best Linear Unbiased Estimation. Beberapa Asumsi klasik pada regresi linear berganda antara lain : Data interval atau rasio, Linearitas, Normalitas residual, Non outlier, Homos-kedastisitas, Non Multikolinearitas, dan Non Autokorelasi.

\section{Metodelogi PENELITIAN}

Agus Priska: Perkembangan riset penggunaan metode AHP ...
Data-data yang diterapkan pada penelitian ini berasal dari publikasi ilmiah diperoleh melalui Google Scholar, ResearchGate dan Neliti.com. Adapun skematik metodologi penelitian yang dilakukan diperlihatkan pada Gambar 3sebagai berikut.

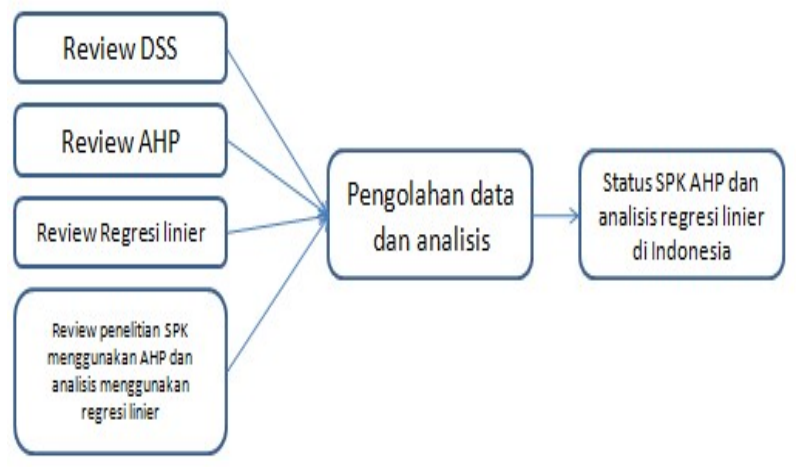

Gambar 3: Skematik Penelitian

Pada tahap Review Decision Support System untuk mengetahui perkembangan yang ada dan bagaimana proses pembangunan dari sebuah sumber yang dimiliki hingga menjadi sebuah DSS yang mampu proses pengambilan sebuah keputusan.

Pada tahap Review Analytical Hierarchy Process(AHP) untuk mengetahui proses ini bahwa AHP benar dapat membantu dalam memecahkan suatu persoalan kompleks dimana AHP menyusun hirarki kriteria, yang akan dinilai dengan subjektif dari pihak berkaitan / memerlukan kemudian menarik berbagai kemungkinan untuk mengembangkan suatu bobot atau prioritas (kesimpulan) serta bagaimana penerapannya dalam pengisian nilai tiap kriterianya.

Pada tahap Review Multiple Linear Regression digunakan agar dapat menguji seperti apa hubungan sebab dan akibat diantara Variabel Faktor Penyebab $(X)$ kepada Variabel Akibatnya $(Y)$.

Pada tahap pengolahan data dan analisis dilakukan untuk mengolah data dari sumber untuk menyesuiakan dengan kebutuhan analisis yang berguna untuk memaksimalkan performance dari sistem yang dibangun.

Pada tahap Review penelitian Decision Support System (DSS) with Analytical Hierarchy Process (AHP) dan Multiple linear regression sebagai metode analisis pengaruh penggunaanya ini berfungsi untuk mengetahui perkembangan metode ini sampai saat ini sebagai acuan dalam pengembangan sistem DSS dimana dalam penerapan AHPnya akan berfokus pada pengisian nilai kriterianya yang akan dirancang dan dibangun.

Pada tahap status dapat dilihat sebagai metode analisis pengaruh penggunaanya di Indonesia menggambarkan bagaimana perkembangan dan pemanfaatan DSS dari instansi pemerintah, swasta, akademik, rumah sakit dll. Sehingga menjadi ide untuk pengembangan Decision Support System (DSS) pada penelitian selanjutnya.

\section{HASIL DAN PEMBAHASAN}

Penelitian DSS with AHP dan MLR sebagai metode analisis pengaruh penggunaanya ini mentelaah dari berbagai jurnal dan artikel yang bisa dicari menggunakan kata kunci "Decision

$$
\text { p-ISSN:1693 - 2951; e-ISSN: 2503-2372 }
$$


Support System", "Analytical Hierarchy Process", "AHP", "Multiple linear regression". Telaah detil dari setiap paper disajikan di bawah ini.

A. Penelitian DSS with AHP dan Multiple linear regression sebagai metode analisis pengaruh penggunaanya di Indonesia

Impelementasi Decision Support System (DSS) sangat berguna bagi sebuah perusahaan maupun instansi. Hal wajib yang harus di fokuskan adalah sebagaimana adanya Decision Support System bukanlah diperuntukan menggantikan pekerjaan manajer, akan tetapi hanya sebagai alat penunjang bagi pemberi keputusan. DSS sebenarnya dapat dikatakan sebagai implementasi teori-teori decision making yang dikemukakan oleh ilmu pengetahuan seperti operation research serta management science, dimana perbedaannya jika dulu dalam mencari problem solving maka dicari secara manual dalam melakukan perhitungan iterasi agar menemukan nilai maksimum, minimum, atau optimum, sementara sekarang computer telah dapat memberikan kehebatanya dalam menyelesaikan masalah yang serupa dengan waktu yang lebih cepat. DSS dikatakan sebagai sebuah sistem pada komputer yang mampu mengolah data ke dalam sebuah bentuk informasi untuk dapat mengambil sebuah keputusan permasalahan semiterstruktur dimana hal tersebut bisa dikatakan spesifik. DSS merupakan problem solver yang disertai kemampuan menghasilkan berbagai laporan berkala dan output dari model matematika.

Berpedoman pada penelitian yang dilakukan oleh Ahmad Faisol dkk dimana penelitian bertujuan untuk menguji dan menganalisa terkait membandingkan Fuzzy AHP dan AHP dimana penerapanya pada SPK investasi dalam properti. Pada penelitian ini kelemahan proses pembobotan pada kriteria maupun subkriteria menggunakan metode FAHP adalah dimana FAHP memerlukan lebih banyak waktu jika dibandingkan dengan memproses dengan metode AHP. Disisi lain FAHP mempunyai kelebihan dimana pada saat proses pembobotan alternatif, FAHP mampu lebih cepat ketimbang AHP. Pada kelebihan lainnya metode FAHP mempunyai tingkat akurasi $84,62 \%$ lebih besar ketimbang penggunaan metode AHP dalam hal kesesuaian hasil rekomendasi sistem investasi properti [9].

Ria Resti Puspita Sari (2017) menerapkan metode AHP dalam keputusan untuk memilih aplikasi chatting pada group sesama pengguna smartphone khususnya android. Penelitian ini terkait mencari tahu prioritas yang ditentukan tiap pengguna smartphone dalam menentukan aplikasi pesan dalam group atau komunitasnya, tiap kriteria-kriteria dalam memilih aplikasi pesan untuk group dianalisis menggunakan metode AHP (Analitycal Hierarchy Process) yang dapat mengurutkan dari terbaik hingga terburuk. Terdapat empat kriteria utama pada penerapan metode AHP pada penelitian ini yaitu jumlah pemakai dengan hasil prioritas 0,064 , fitur dengan hasil prioritas 0,136 , kecepatan akses dengan hasil prioritas 0,262 , kemudahan pengguna dengan hasil prioritas 0,539. Tiga alternatif yang menjadi pertimbangan yaitu BBM, Line, Whatsapp. Hasil akhir penelitian ini terkait aplikasi pesan group yang ditentukan oleh tiap pengguna android smartphone dimana dengan nilai tertinggi adalah Whatsapp 0,355 (35,5\%), lalu BBM bernilai 0,333 (33.3\%), dan paling terakhir adalah LINE bernilai $0,312(31.2 \%)[10]$.

Agnia Eva Munthafa dkk (2017) menerapkan AHP pada sistem pendukung keputusan pada saat menentukan mahasiswa paling berprestasi. Pada penelitian ini menjabarkan beberapa kekurangan dan kelebihan metode AHP. Pada kekurangannya dimana model ahp ini dimana input awal merupakan hal yang sangat riskan dan berpengaruh besar terhadap hasil sehingga dalam hal ini subyektifitas sang ahli akan terlibat. Sedangkan pada sisi kelebihannya AHP menjadikan luasnya permasalahan serta tidak terstrukturnya menjadi suatu yang mudah untuk dipahami. AHP bisa menjadi alat bantu untuk penentuan murid terbaik dimana didukung oleh data kuantitatif dan tingkat validitas konsistensi hierarki. Peran penilai untuk mengerti sebuah konsep AHP sangat berpengaruh dilihat dari Tingkat validitas sebuah rekomendasi alternatif yang ditentukan oleh pembobotan kriteria. Keluaran dari studi ini adalah sistem mampu menghadirkan berupa rekomendasi pilihan untuk gelar mahasiswa yang memiliki prestasi dimana nilai indeks konsisten sebesar 0,06 [11].

Dedi Romario dkk (2019), penelitian ini menggabungkan AHP dengan TOPSIS dimana TOPSIS dapat dikatakan sebagai metode gabungan mendukung pengambilan keputusan untuk merekomendasikan pekerja. AHP digunakan mencari bobot kriteria yang diprioritaskan dan TOPSIS untuk mengurutkan pilihan pekerja. Penelitian ini menunjukan matriks perbandingan pada AHP berguna dalam menentukan bobot prioritas kriteria, namun metode AHP juga memiliki kekurangan yaitu batasan jumlah kriterianya agar mendapatkan nilai RI. Pada kasus ini disarankan menggunakan penggabungan metode untuk menangani kasus yang memerlukan lebih banyak kriteria. Dari hasil pengujian akurasi diperoleh akurasi aplikasi $69 \%$ untuk rekomendasi pekerja tetap, $50 \%$ pembaruan kontrak, serta $80 \%$ untuk putus kontrak. Pada penelitian ini tidak adanya analisis seberapa besar dampak penggunaan dari metode penilaian terhadap peningkatan motivasi maupun kinerja kariawan [12].

Hendry Susilo dkk (2017), penelitian ditujukan untuk mengetahui penerapan AHP ketika menentukan kriteria alternatif dalam penempatan posisi pekerja di CV. Jasindo. Penelitian ini menggunakan metode kuantitatif, seperti diketahui pada metode ini angket, wawancara, observasi, dan studi pustaka digunakan untuk pengumpulan data. Pada penelitian ini AHP dapat mengukur konsistensi secara menyeluruh dari berbagai pertimbangan dengan rasio konsistensi. Penelitian ini berfokus pada 3 aspek kriteria utama yaitu Pendidikan, Kepribadian, Latar belakang. Dari 3 aspek tersebut menampilkan 11 kriteria dimana penempatan karyawan didasarkan pada pendidikan formalnya menjadi yang prioritas tertinggi sebesar 0,174 . Pada penelitian ini menunjukan AHP menghadirkan metode yang lebih bagus untuk penyelesaian terkait penempatan karyawan agar dapat langsung digunakan karena rasio inkonsistensi masing-masing kriteria dapat diterima. Pada penelitian ini perlu adanya analisis pengaruh penerapan AHP terhadap kepuasan kariawan [13].

Nawal Sael dkk (2019) memanfaatkan potensi teknik AHP, dalam menganalisis profil siswa. Tujuan penelitian ini mencari tahu serta mengklasifikasikan faktor-faktor krusial yang meningkatkan putus sekolah dan kegagalan para siswa di Maroko, mempelajari konteks Maroko dan mendeskripsikan 
profil siswa tergantung pada kriteria varian. Penelitian ini menunjukan bahwa AHP memungkinkan untuk mengklasifikasikan faktor terpenting yang mempengaruhi siswa keluar. Berdasarkan temuan tersebut, tiga faktor utama yang menyebabkan siswa putus sekolah adalah: Fakultas akses terbuka Maroko adalah: kurangnya orientasi, kegagalan berulang untuk memvalidasi modul dan kurangnya motivasi [14].

Moh Ramdhan Arif Kaluku dkk (2017), Pada penelitian ini menggunakan dua metode yaitu AHP dan ANP dalam mencari bobot pada tiap kriteria dengan parameter nilai yang digunakan agar nantinya bobot prioritas didapatkan, lalu digunakan pada perhitungan metode TOPSIS. Dalam melakukan penilaian kinerja pada penelitian ini yang menerapkan AHP dan ANP diawali dengan menggunakan kriteria untuk analisis validitas dari pengukuran kinerja yang berasal oleh penilaian KPI dimana evaluasi untuk mengukur pengaruh antara kriteria. Dari hasil perbandingan berpasangan metode AHP diperoleh vektor prioritas yang kemudian menghasilkan bobot umum dari setiap subkriteria. Sedangkan hasil analisis ANP mengeluarkan bobot umum dimana bobot tersebut diperoleh melalui limit supermatriks dan limit tersebut nantinya digunakan dalam perhitungan dengan metode TOPSIS. Hasil akhir studi yang didapat menggambarkan perbandingan kedua metode dimana disimpulkan dengan menggunakan metode $A H P-T O P S I S$ nilai kinerja yang diraih 0,6549 sedangkan 0,5906 diraih saat menerapkan metode ANP-TOPSIS [15].

Yudhamanik Kusuma dkk (2017) dalam menentukan pemanfaatan aset tanah pemda dengan sistem informasi geografis dan metode AHP. Penelitian ini berlokasi di Pemprov Bali. Pada penerapan metode AHP penelitian ini menggunakan 7 kriteria utama yakni bentuk medan, ketinggian, jenis tanah, kualitas lalulintas, kedalaman tanah, tekstur tanah. Pada Penelitian ini kualitas lingkungan merupakah kriteria yang paling memiliki pengaruh kuat dalam pembobotan terhadap aset tanah HP.129 serta P.16. Pada aset tanah P.16 dipilih dimanfaatkan untuk tanaman padi itu dikarenakan tanaman padi memperoleh bobot $25,26 \%$ dan nilai tersebut merupakan nilai tertinggi dibandingkan tanaman kedelai (24,24\%). Pada aset tanah HP129 memperoleh bobot paling tinggi sesuai hasil proses AHP pada pemanfaatanya sebagai fasilitas umum dimana memiliki bobot 57,04\%. Dapat dilihat disini penggunaan metode AHP efektif untuk penentuan dalam pemanfaatan aset tanah terutama pemanfaatan aset tanah milik Pemprov Bali [16].

Rafhael Stevanus dkk (2019), pada penelitian ini dilakukan di Rumah Sakit Buah Hati. Penelitian penerimaan bonus pegawai pada Rumah Sakit masih dilakukan dengan perorangan dimana pemberian keputusan reward masih belum sesuai tempatnya. Dari penelitian penerapan AHP ini penulis melihat setidaknya ada empat kriteria dalam perbandingan berpasangan yang ada pada Rumah Sakit pada tahap pemberian bonus, seperti: Sikap \& Perilaku, Keahlian, Tanggung Jawab, dan Loyalitas. Kriteria utama yang paling diprioritaskan pada penelitian ini adalah kriteria Keahlian dimana keahlian memperoleh bobot nilai sebesar 0,317 atau $32 \%$, sedangkan pekerja paling diutamakan adalah Zuliana dengan bobot 0,587 atau 59\%. Pada penelitian juga perlu di analisis terkait kepuasan pekerjaterhadap sistem [17].

Agus Priska: Perkembangan riset penggunaan metode AHP ...
Mukhammad Hilmi Muzakki dkk (2016), Tujuan utama penelitian agar mengetahui dampak penggunaan dari teknologi informasi dan bagaimana dampaknya kepada kinerja pegawai. Pengujian terhadap hipotesa menggunakan Multiple Linear Regression dimana diduga variabel kemudahan (X1) dan variabel kemanfaatan (X2) memiliki dampak simultan terhadap kinerja pekerja (Y). Pada akhirnya penelitian menghasilkan sebuah kesimpulan bahwa pada variabel bebas memiliki dampak pengaruh kuat terhadap Kinerja pekerja secara parsial dan simultan. Dari hasil Multiple Linear Regression menyatakan variabel bebas memiliki dampak yang kuat kepada variabel terikat dimana kinerja pekerja sebesar 52,8\%. dimana $47,2 \%$ adalah variabel lain yang mampu memberi dampak terhadap kinerja pekerja antara lain ability dan motivasi pekerja. Sesuai hasil uji F diperoleh bahwa nilai F hitung senilai 55,345 yang mendefinisikan variabel kinerja pekerja (Y) secara signifikan dipengaruhi oleh variabel independen kemudahan dalam penggunaan TI (X1) serta Manfaat penggunaan TI (X2). [18].

Desi Ratna Sari dkk (2018), Penelitian ini terkait usulan sebuah SPK dalam penentuan kelulusan saat sidang skripsi dengan menerapkan metode AHP dan TOPSIS. Pada penelitian ini AHP digunakan untuk bobot untuk memperoleh nilai tiap kriteria, dimana nilai keluaran tiap kriteria diperuntukan untuk memperoleh peringkat alternatif menggunakan TOPSIS. Ada 5 kriteria dalam penilaian yaitu bab tulisan, penyampaian bahan, tata krama, kerapian, serta penguasaan bahan. Prioritas kriteria yang diterapkan seperti penguasaan bahan menjadi lebih penting dari bab tulisan, dan bab tulisan sedikit lebih penting daripada kerapian, tata krama dan penyampaian materi. Penggabungan dua metode AHP dan TOPSIS bisa memaksimalkan bobot nilai kriteria berdampak ke hasil peringkat alternatif semakin objektif. Jarak Hamming diperoleh 96,2\% serta jarak Euclidean 0,8096 pada 95 murid [19].

Bartolomius Harpad dkk (2017), Pada penelitian berfokus pada SPK penerimaan asisten laboratorium. AHP dan Metode TOPSIS adalah dua Metode yang digunakan pada pengambilan keputusan dalam proses pemilihan asisten laboratorium. Pada proses seleksi ada beberapa kriteria penilaian yang digunakan pada metode TOPSIS maupun AHP seperti penguasaan materi, wawancara, kemampuan mengajar, disiplin, dan tanggung jawab. Metode TOPSIS berpedoman pada pilihan terbaik tidak hanya diukur dari jarak terpendek dengan solusi positif, tetapi juga harus pada jarak terjauh dari solusi ideal negatif. Pada penelitian ini perlu ditambahkan data kriteria untuk memperkuat hasil seleksi asisten seperti [20].

Frieyadie (2018), Penelitian ini menerapkan metode AHP untuk penentuan pekerja terbaik. Pada penelitian ini menerapkan 5 kriteria yaitu sikap, Absensi, Tanggung jawab, Kedisiplinan, Kerjasama. Hasil yang diperoleh menyatakan bahwa pekerja paling sesuai adalah Pekerja A dengan unggul persentase sebesar $23 \%$ berbanding dengan pekerja E sebesar $22 \%$. Pada penelitian ini menunjukan faktor terpenting prioritas penilaian kinerja adalah tanggung jawab dimana bobotnya 0,349 atau 35\%. Pada penelitian ini tidak berlanjut hingga ke tahap pengukuran dampak penggunaan AHP terhadap motivasi maupun kinerja kariawan, sehingga reviewer tidak dapat mengetahui sejauh mana dampak penerapanya terhadap efektivitas pekerja [21].

p-ISSN:1693 - 2951; e-ISSN: 2503-2372 
Julius Santony dkk (2019) menerapkan AHP untuk meningkatkan jenjang karir karyawan. Penerapan AHP pad apenelitian ini terdapat 4 kriteria utama dengan kriteria eigen yang diperoleh sebagai berikut planning $(0,233)$, teaching $(0,061)$, evaluating $(0.105)$, dan learning $(0,602)$. Hal itu menunjukan Aplikasi Decision Support System (DSS) yang mampu memberikan hasil yang diperoleh dari pengujian perhitungan bahwa alternatif pegawai terbaik dengan perhitungan 0,227 diraih oleh Pegawai $\mathrm{C}$ dibandingkan pilihan lainnya. Penerapan SPK menggunakan metode AHP memiliki akurasi data senilai $86.67 \%$ serta bisa membantu manajer dalam membuat rekomendasi untuk peningkatan jenjang karir karyawan. Namun adanya pengukuran dampak penggunaan AHP terhadap motivasi maupun kinerja kariawan. Sehingga pembaca dapat mengetahui sejauh mana dampak penerapanya terhadap efektivitas pekerja [22].

I Gusti Ngurah Wira Partha dkk (2019), pada penelitian ini bertujuan Merancang SPK Pemilihan Karyawan Terbaik dengan Metode AHP agar bisa membantu Departemen HRD di PT. Z Bali. Penelitian ini menggunakan 4 kriteria utama dengan priority sebagai berikut : disiplin $(0,42)$, responsible $(0,27)$, skill $(0,19)$, dan cooperation $(0,12)$. Pada akhir penelitian ini dapat disimpulkan bahwa dalam melakukan pemilihan pegawai terbaik dengan proses perhitungan menggunakan AHP, memiliki nilai akurasi yang lebih tepat daripada dilakukan dengan kalkulasi manual. Selain itu Perancangan SPK untuk seleksi pegawai terbaik telah berhasil dibangun untuk PT. Z Bali. Pada penelitian ini tidak adanya analisis seberapa besar dampak hasil penggunaan dari sistem terhadap kepuasan manajemen khususnya departemen HRD [23].

Yaning Tri Hapsari (2018), penelitian ini mengukur faktor intangibles kualitas dan brand yang dapat memberi pengaruh dalam menentukan harga jasa laundry. Lama pengerjaan, prosedur pelayanan, merek, teknik pengerjaan, dan strategi marketing adalah kriteria intangibles berpengaruh kepada harga jual. Dari kelima kriteria tersebut dikelompokan menjadi faktor kualitas yang terdiri dari kriteria dan faktor brand yang terdiri dari Teknik pengerjaan, lama pengerjaan, dan prosedur pelayanan. Sedangkan brand dan strategi marketing masuk ke faktor merek. Bobot paling tinggi hasil proses AHP yang diperoleh adalah lama pengerjaan senilai 0,356. Dari kelima kriteria yang diterapkan dapat disimpulkan faktor intangibles kualitas mempunyai bobot tertinggi yaitu 0,73 , sedangkan brand bernilai 0,27. Dari hal itu disimpulkan bahwa kualitas punya dampak yang lebih kuat dari merek saat menetukan harga jual [24].

Nani Agustina (2014), penelitian mengambarkan tentang Sistem Pendukung Keputusan Pemilihan Browser pada Android. Metodologi yang diimplementasikan dalam penelitian adalah AHP dengan menentukan tujuan penelitian untuk membantu pengguna smartphone Android dalam memilih browser yang sesuai dengan kebutuhan, berdasarkan kriteria iklan, interface, kecepatan, memori dan memberikan alternatif pilihan browser. Dari hasil penelitian kriteria utama dalam menggunakan browser di Android adalah browser tersebut memiliki interface yang user friendly, iklan yang minimal, kecepatan browser dalam layanan server ke pengguna dan memori yang diperlukan smartphone Android untuk menginstal aplikasi browser tersebut kecil. Sedangkan prioritas pilihan berdasarkan kriteria tersebut Google chrome lebih unggul karena browser Google chrome memudahkan pengguna untuk berintegrasi dengan aplikasi yang banyak didukung oleh Google Inc. [25].

Mhd Sandi Rais dkk (2016), pada penelitian ini merancang model SPK yang akan di terapkan pada Pemilihan beberapa Lokasi Perumahan dengan Analytical Hierarchy Process $(A H P)$. SPK ini dapat menolong pimpinan sebuah perusahaan ketika memutuskan perumahan yang layak dipilih. Studi ini berfokus pada perancangan dan pengimplementasian aplikasi super dicision serta dapat mempermudah dalam memilih lokasi. Pada penelitian ini menggunakan beberapa kriteria dalam penentuan keputusan, yaitu : Lokasi Perumahan dengan nilai eigen 0.295, Harga Rumah dengan nilai eigen 0.080, Fasilitas Perumahan dengan nilai eigen 0.090 serta Desain Rumah dengan nilai eigen 0.106 dan Perizinan Perumahan dengan nilai eigen 0.465. Sebagai sebuah keputusan maka nilai akhir nantinya akan menjadi penentu status dari Perumahan. Pada akhirnya penelitian ini telah berhasil memudahkan konsumen dalam memilih lokasi perumahan. Bentuk form format pada penilaian oleh sistem ber-impact pada meminimalkan kesalahan saat memberikan sebuah penilaian. [26].

Sean A.M. Pebakirang dkk (2017), penelitian menerapkan ini menerapkan AHP guna membantu dalam memilih supplier sebuah suku cadang. Penelitian menerapkan desain AHP dimana terdiri dari 5 kriteria utama yaitu harga barang, ketersediaan barang, kualitas barang, kuantitas barang, dan kontinuitas. Pada level subkriteria terdiri dari 3 perusahaan supplier. Dari penerapan metode AHP pada penelitian ini berhasil menentukan pemilihan supplier suku cadang dimana dalam menetukan prioritasnya dengan memperhatikan kriteria prioritas dengan nilai tertinggi. Dari hasil proses AHP diraih bahwa PT. XXX (2.4174) sebagai penyuplai suku cadang terbaik [27].

Yogi Prihartono (2016), penelitian ini terkait pengembangan SPK dalam penentuan Internet Service Provider paling baik di Pangkalpinang dengan menerapkan metode $A H P$. Sesuai uraian serta susunan kriteria alternatif maka dibentuk dari enam kriteria, dua puluh subkriteria, dan lima alternatif, dimana enam Kriterianya yaitu Kecepatan Kirim Data, Kemudahan dalam penggunaan, Batasan akses internet, Tipe Layanan, Tingkat jaringan serta Jenis pada kartu. Tiap kriterianya didapatkan kesimpulan bahwa kriteria yang diutamakan adalah Kecepatan dalam melakukan Transfer Data dengan nilai bobot 0,401 atau dalam persentase adalah $40,1 \%$ dari total semua subkriteria. Pada akhirnya cukup konsisten merupakah hasil dari gabungan data responden yang telah dilakukan perhitungan geometrik [28].

Bayu Marga Indra Pangestu (2018), pada penelitian ini berlokasi pada Kopkar Faustine Hotel Semarang yang menerapkan metode AHP saat menentukan kelayakan seorang nasabah dalam akan menerima sebuah Kredit. Dalam penentuannya, kriteria yang menjadi pertimbangan dasar pengambilan sebuah keputusan dimana diantaranya nilai penghasilan calon kreditur, nilai pinjaman, masa kontrak, angsuran, jangka waktu pinjam dan jaminan. Desain pemodelan tahap awal menerapkan data Flow diagram serta Activity Diagram. Keluaran akhir studi dimana hasil urutan prioritas global dari tertinggi hingga paling rendah kriteria tiap nasabah, menjadikan pihak Hotel mudah dalam pengambilan keputusan dimana mereka dapat melihat hasil akhir secara baik. 
Kelemahan penelitian ini adalah tidak adanya penggunaan metode lain, perlunya penggabungan metode sehinggadapat menguatkan keputusan yang dihasilkan [29].

Meilin Widyastuti dkk (2017), pada penelitian ini meneliti terkait perkembangan aksesoris handphone dimana nantinya akan menghasilkan sebuah rekomendasi berdasarkan penilaian toko aksesoris handphone, dari yang paling diminati konsumen. Pada kasus ini hubungan antara kriteria dengan alternatif dalam AHP terdiri dari 6 kriteria antara lain phone ring, screan guard, charger wareless, led selfi, handset, gopro. Hasil akhir dalam penerapan metode AHP menggunakan enam contoh aksesoris pada handphone yang paling laku di pasaran, dimana data didapat dari hasil wawancara pada tiap toko asesoris di kota Pematangsiantar, maka diperoleh hasil akhir perhitungan menggunakan metode AHP dalam rekomendasi aksesoris hp diamana Led Selfie di urutan pertama (34\%), lalu kedua Gopro (25\%), ketiga Phone Ring (20\%), keempat Screen Guard (16\%), kelima Charge Wireless $(14 \%)$ dan yang terakhir Handset $(10 \%)$. Pada kasus ini hanya ada satu level kriteria tanpa adanya subkriteria sehingga penggunaan AHP masih kurang di efektif [30].

R. Randy Valdika dkk (2019) menerapkan metode fuzzy Analytical Hierarchy Process pada saat menganalisis ancaman multi bencana pada kabupaten kendal. Dalam penerapan metode pembobotan tiap kriteria bencana variasi dengan metode pembobotan menggunakan Fuzzy AHP beserta Katalog Methodologi Penyusunan Peta Geo Hazard. Hasil yang didapat dimana tingkat akurasi output pemodelan ancaman bencana dengan metode FAHP dimana yang tertinggi adalah untuk ancaman tanah longsor $85 \%$, kemudian ancaman kekeringan $82,5 \%$ dan untuk ancaman banjir adalah $75 \%$. Sementara itu sebaran tiap wilayah pada kelas ancaman multi bencana pada tingkat rendah didapat luas ancaman 28773,774 Ha serta tersebar pada tiap kecamatan di Kabupaten Kendal [31].

Julita Gandasari Ariana (2018), penelitian menerapkan Metode AHP dengan Push Notification dalam merancang Aplikasi Pengelolaan Bahan Baku Kafe agar dapat menjaga kualitas pelayanan. Pada prosedur AHP yang diterapkan, dilakukan pembobotan pada tiga kriteria, seperti jumlah menu yang digunakan dengan bahan, sisa bahan, dan harga. Pada nilai bobot dipakai saat melakukan perankingan pilihan yang tersedia berupa bahan baku yang siap untuk dbeli lebih dahulu. Pada akhirnya dengan menerapkan kedua metode diperoleh hasil terkait pengujian dari akurasi hasil proses AHP sebanyak $68 \%$, serta tingkat kesuksesan dalam pengiriman dengan push notification sebanyak $80 \%$. [32].

Wahyu Novitasari dkk (2016), penelitian ini berfokus dalam mengukur pengaruh penggunaan handphone kepada social interactions anak pada rentan umur 5-6 tahun. Sesuai hasil studi ini nilai perhitungan uji Simple Linear Regression t adalah signifikan dimana nilai yang diperoleh 0,000 serta t hitung nilai yang diperoleh 12,758 , secara langsung menggambarkan fakta adanya pengaruh penggunaan gadget kepada social interactions antar anak pada umur 5-6 tahun. Melihat kalkulasi perhitungan yang didapat maka dapat ditarik bahwa social interactions anak pada umur 5-6 tahun dapat dipengaruhi oleh pemakaian handphone [33].

Matias Kristian Kelviandy (2014), penelitian ini menerapkan Analytical Hierarchy Process dalam analisis

Agus Priska: Perkembangan riset penggunaan metode AHP ... pengambilan keputusaan dalam menetapkan Operating System pada sebuah smartphone berdasarkan tingkat aktivitas penggunanya di masyarakat. Beberapa kriteria yang digunakan pada penelitian ini seperti Kemudahan, Keamanan, Privasi, Kenyamanan, Layanan, Keluwesan, Kecepatan. Dari rata-rata hasil perhitungan, faktor keamanan lah yang merupakan hal terpenting bagi Alternatif Hasil. Dimana dapat dilihat sebagai berikut: Android * 0.4474 44.74\% Windows $0.100110 .01 \%$ IOS $0.3590 \quad 35.90 \%$ Rim $0.09369 .36 \%$ masyarakat ketika memperhitungkan kriteria operating system sebuah smartphone, dengan nilai persentase $24.66 \%$, kemudian ada nyaman $(15.19 \%)$, pelayanan $(20.80 \%)$, privasi $(12.41 \%)$, keluwesan (6.84\%), kecepatan (14.41\%), serta mudah dalam menggunakan (5.69\%). Dapat ditarik disimpulkan dimana OS android dapat dikatakan sebagai sistem operasi pada smartphone yang punya banyak kelebihan dalam segi keamanan, keluwesan, serta layanan [34].

Alex Siswanto dkk (2018), Pada penelitian ini berfokus pada penerapan Analytical Hierarchy Process pada SPK dalam pembagian beasiswa "Program Jont Degree" Universitas Bhayangkara Surabaya. Dalam penelitian ini mempunyai empat kriteria yang digunakan pada AHP yaitu nilai TOEFL, nilai TPA, nilai IPK dan Komunikasi. Perbandingan berpasangan berpedoman pada kebijakan oleh penilai. Berikut penggambaran dalam penilaian permasalahan ini: Kriteria nilai TOEFL sedikit lebih penting ketimbang nilai Komunikasi dan sedikit lebih penting ketimbang nilai TPA. Kriteria TPA sedikit lebih penting ketimbang nilai Komunikasi. Kriteria nilai IPK lebih penting ketimbang nilai Komunikasi, 4 lebih penting ketimbang nilai TPA dan sedikit lebih penting ketimbang nilai TOEFL. Pada hasil akhir penelitian ini, menghasilkan sistem aplikasi yang dapat melakukan perhitungan dalam kelayakan penerima beasiswa Program Joint Degree pada Universitas Bhayangkara Surabaya. Sesuai yang didapat dari percobaan pada empat jurusan dengan penerapan AHP, maka diperoleh hasil rangking nilai tiap mahasiswa sesuai dengan jurusannya. Keluaran sistem menunjukan dua mahasiswa dimana mereka dengan nilai tertinggi yang mendapat beasiswa [35].

Lolasari Novelly Hutabarat (2019), Penelitian berfokus pada pengukuran pengaruh pengawasan, budaya dan remunerasi terhadap motivasi kerja. Penelitian ini menerapkan metode analisis Multiple Linear Regression. Melihat hasil hitung dimana $\mathrm{F}_{\text {hitung }}$ bernilai 23.758 lebih besar dari $\mathrm{F}_{\text {tabel }}$ dan signifikan (Sig.) kurang dari 0.05 mengartikan bahwa budaya, pengawasan, dan remunerasi memiliki pengaruh positif terhadap motivasi kerja. Hal itu didukung oleh keluaran analisis regresi secara menyeluruh mengartikan nilai Adjusted $\mathrm{R}$ Square(R2) sebesar 0,636 korelasi motivasi kerja (dependen) dengan budaya perusahaan, pengawasan, dan remunerasi (independen) mempunyai korelasi kuat $63,6 \%$ selebih dari faktor faktor lain diluar penelitian ini [36].

Ririn Ikana Desanti dkk (2017), penelitian membahas tentang aplikasi web penerimaan serta penilaian karyawan pada PT. XYZ. Dimana metode AHP penelitian ini diterapkan dalam memilih dan memberi peringkat pelamar berdasarkan beberapa kriteria dimana kriteria berpedoman pada perhitungan metode AHP dengan menerapkan matriks pairwise comparison. Pada penelitian ini menerapkan empat kriteria utama yaitu jurusan, ipk, jenjang pendidikan, pengalaman kerja.pada akhirnya

$$
\text { p-ISSN:1693 - 2951; e-ISSN: 2503-2372 }
$$


pengembangan sistem dengan penerapan metode AHP pada penelitian ini berhasil mempercepat proses seleksi dengan hasil yang akurat [37].

Puji Kurnia Putri dkk (2019) melakukan penelitian yang berlokasi di kota Tangerang terkait dalam menangani pembelian rumah di kota Tangerang. Beberapa kriteria yang menjadi bahan analisis dalam penerapan AHP penelitian diantaranya lokasi, spek bangunan, harga, kredibilitas pengembang dan metode pembayaran. Pengolahan AHP menggunakan expert choice. Kriteria dalam pemilihan lokasi mendapatkan bobot tertinggi $30 \%$. Pada penelitian ini menyimpulkan dalam mengambil keputusan multi kriteria beserta multi alternatif sangat sesuai dalam proses AHP. Poris Residence menjadi prioritas utama dalam memilih pemilihan perumahan berdasarkan pilihan yang ada. Pada penelitian ini seharusnya dapat ditambahkan beberapa kriteria kriteria lain yang menjadi pertimbangan di masyarakat dalam memilih suatu perumahan untuk menguatkan akurasi hasil. Pada akhirnya oleh karena perhitungan metode AHP konsisten dengan penambahan kriteria maka hasil keluaran yang diperoleh dari sistem bisa dipertanggungjawabkan [38].

Gde Brahupadhya Subiksa (2018) menerapkan Metode AHP pada rekomendasi sebuah Keputusan dalam menentukan SIM Card Provider. Beberapa kriteria yang digunakan pada penelitian ini seperti telepon, SMS, Paket Internet, Paket Blackberry, dan Bonus. Pada alternatif yang ada adalah beberapa kartu familiar di indonesia seperti axis, 3, aha, flexi, smartfriend dan lainya. Hasil penerapan AHP dalam pemilihan kartu perdana provider menghasilkan sebuah rekomendasi kartu perdana provider berdasarkan dengan kebutuhan penggunannya serta dapat membantu dan mempermudah penggunanya dalam menentukan kartu perdana provider. Membuat SPK dengan penerapan AHP memerlukan tampilan yang mendukung untuk meningkatkan kepuasan pengguna sistem [39].

Salah satu penelitian terkait analisis pengaruh penerapan SPK dilakukan oleh Siti Khoirina dimana dalam penelitiannya mencari pengaruh pada sistem pengukuran kinerja beserta kejelasan peran terhadap kinerja. Pada sampel penelitianya menggunakan kuesioner dalam mengetahui seberapa besar SPK bersifat komprehensif dengan tujuh point skala likert. Pada penelitian ini menerapkan teknik Path Coefficient yang menghasilkan kesimpulan bahwa sistem ukur kinerja bisa meningkatkan dari kinerja, dimana hasil dari pengujian dengan menerapkan partial least square (PLS) maka diketahui bahwa SPK memiliki pengaruh langsung kepada kinerja pekerja [40].

Hasil review penelitian diatas menunjukan bahwa penerapan metode Decision Support System (DSS) dengan menerapkan Analytical Hierarchy Process (AHP) dapat dilakukan pada lembaga pemerintah, instansi pendidikan, instansi kesahatan dan perusahaan. Adapun tujuan yang dimiliki adalah untuk membantu mempercepat dan akurasi pengambilan dari sebuah keputusan. Perkembangan Penggunaan DSS yang menerapkan AHP di Indonesia tentunya juga memiliki grafik dan disini peneliti mendapatkan jumlah data penelitian terkait dari Neliti.com sebagai berikut.

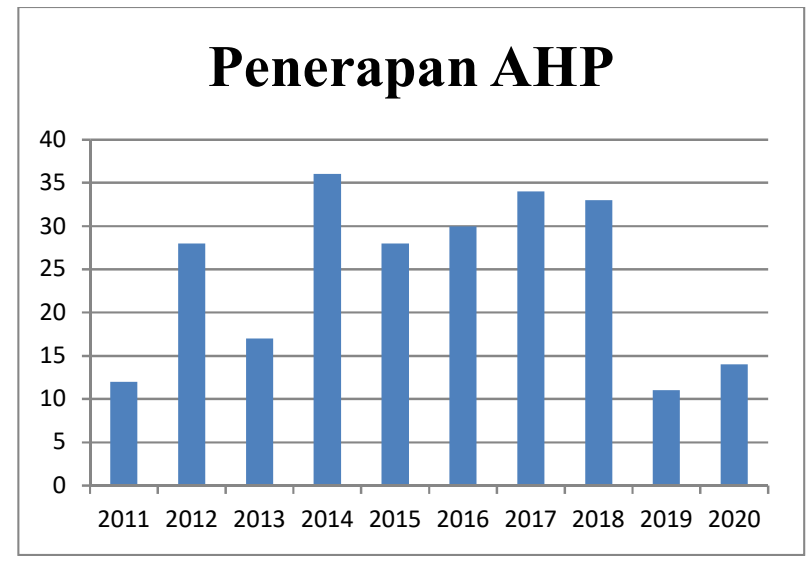

Gambar 4 Penelitian DSS dengan penerapan metode AHP 2011-2020

Berdasarkan penelitian Analytical Hierarchy Process (AHP) dari tahun 2011-2020 terjadi peningkatan paling signifikan pada tahun 2014, data tersebut bersumber pada laman pencarian penelitian Neliti.com dengan kata kunci Analytical Hierarchy Process di Indonesia. Adapun dalam objek instansi pada lembaga yang ada di Indonsesi terdiri dari lembaga pemerintah, rumah sakit, swasta, dan akademik ditunjukan pada Gambar 4.2 sebagai berikut.

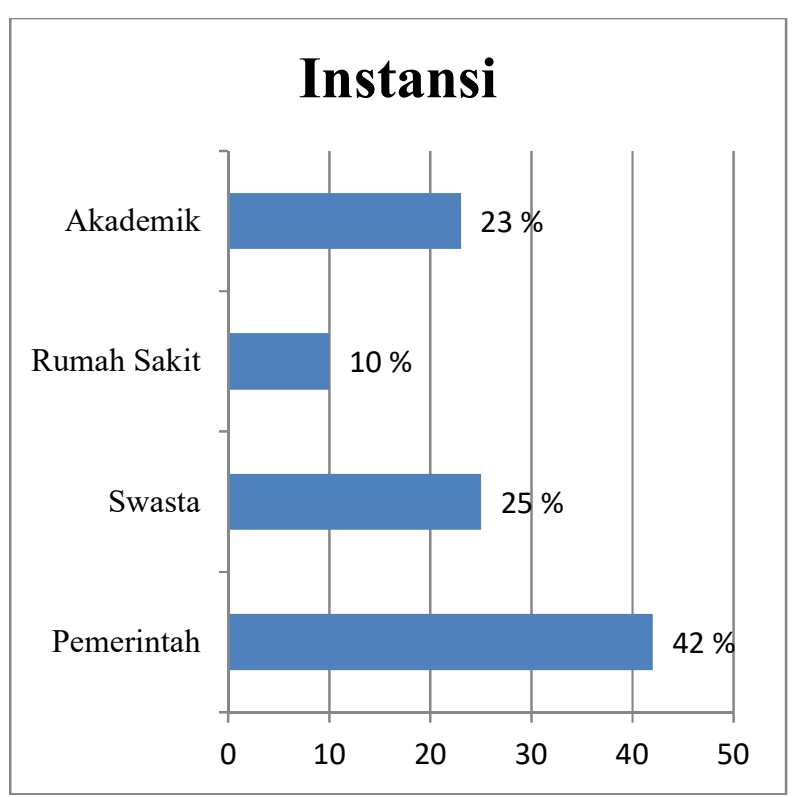

Gambar 5 Instansi Obyek Penggunaan DSS yang menerapkan AHP di Indonesia

Berdasarkan Gambar 5 obyek Penggunaan DSS yang menerapkan AHP paling banyak digunakan pada instansi pemerintahan sebanyak $42 \%$ dimana pemanfaatannya digunakan untuk penyeleksian pekerja berprestasi maupun pemilihan jabatan penting di pemerintahan. Selain itu terdapat juga pemanfaatan penggunaan metode ahp pada pemerintahan untuk pemilihan perangkat pendukung operasional dan pemilihan vendor dalam suatu projek di pemerintahan. Untuk penggunaan yang paling rendah sebanyak $10 \%$ ada pada 
instansi rumah sakit dimana metode AHP digunakan pada penilaian kinerja dan kualitas layanan.

Adapun dalam pengembangan sistemnya dari penerapan Decision Support System (DSS) dengan metode Analytical Hierarchy Process (AHP) terdapat berbagai macam pilihan untuk pengembangan sistem, berikut diantara hasil review penelitian dijabarkan basis data dalam pengembangan dengan diagram pada Gambar 4.3 basis Analytical Hierarchy Process (AHP).

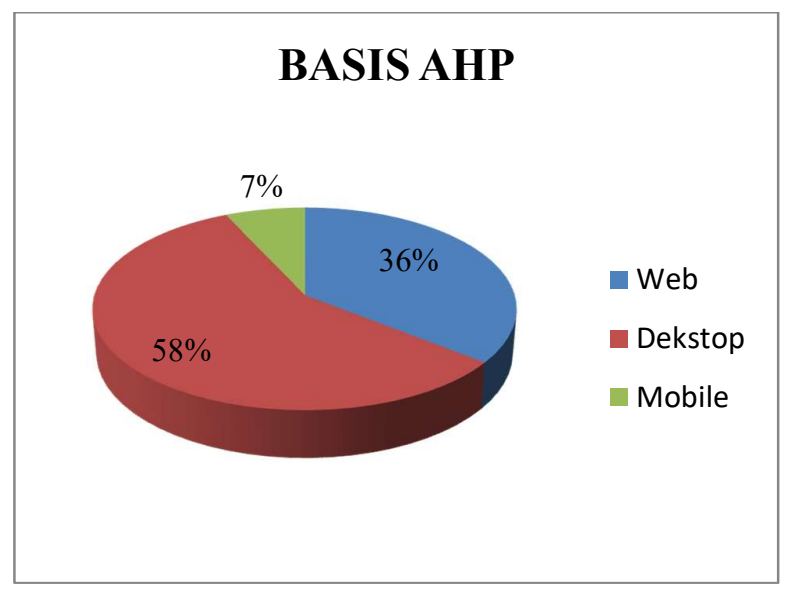

Gambar 6 Basis penerapan $A H P$

Dari Gambar 6 memberikan informasi hasil dimana sistem lebih banyak dibangun berbasis desktop dengan angka $58 \%$. Pada penelitian yang ditelaah pada penggunaan DSS yang berbasis desktop cenderung digunakan karena beberapa alasan, salah satunya adalah penggunaan sistem yang tidak digunakan oleh karyawan umum melainkan hanya pihak-pihak tertentu yang memiliki kekuasaan untuk mengambil sebuah keputusan, selanjutnya tingkat keamanan dari data tersebut lebih mudah untuk dijaga, pada penelitian yang di telaah juga perkembangan Internet belum secepat dan mudah di akses seperti sekarang ini. Akan tetapi hampir setiap penelitian yang membangun sistem berbasis dekstop memaparkan pada saran untuk bisa mengembangkan DSS dengan penerapan metode AHP menjadi sistem yang lebih fleksibel untuk di akses kapan dan dimanapun, sehingga Sistem berbasis web menjadi solusinya, dengan begitu pihak-pihak yang memiliki kuasa dalam proses pengambilan keputusan bisa dengan lebih cepat dan mudah dalam menganalisa data tersebut.

B. Rencana Penerapan Analytical Hierarchy Process

Dari diskusi penelitian di atas terlihat bahwa penelitian Analytical Hierarchy Process baru pada tahap perancangan dan pengujian sistem. Penulis sedang menyusun rencana dalam mengembangkan sebuah sistem informasi dalam mendukung keputusan menggunakan metode Analytical Hierarchy Process serta analisis pengaruh penggunaannya terhadap kinerja pekerja di PT. BRIKS. Perlu diketahui peneliti telah mengembangkan aplikasi "Time Management" dan "Task Management and Performance Report". Kedua aplikasi tersebut menghasilkan "Daily Update Performance" yang menunjukan beberapa report utama seperti yang disebutkan diatas seperti halnya report task management, absensi, insiden Agus Priska: Perkembangan riset penggunaan metode AHP ... report, kerajinan pengisian form, dan penguasaan pengetahuan dan nilai nilai tersebut yang akan secara otomatis menjadi nilai dasar kriteria setiap pekerjanya sehingga tidak perlu dilakukan pengentrian dari admin maupun pejabat secara manual lagi seperti penelitian penelitian sebelumnya yang pernah dilakukan. Pada penelitian ini akan berfokus pada pengentrian bobot nilai oleh sistem dimana tiap nilainya dilihat dari record pekerja pada sistem. Peneliti masih belum banyak melihat analisis dampak sistem SPK terhadap motivasi pekerja setelah penerapanya. Metode Analisis dampak dengan metode Multiple Linear Regression diperlukan untuk mengukur efektivitas penggunaan sistem terhadap motivasi pekerja perusahaan. Sistem Informasi Manajemen nantinya akan mendukung keputusan status pekerja BRIKS Tabanan menggunakan metode AHP. Sistem akan dibuat berbasis web sehingga akan mempermudah pengguna dalam aksesnya. Adapun Gambaran umum sistem yang dikembangkan sebagai berikut:

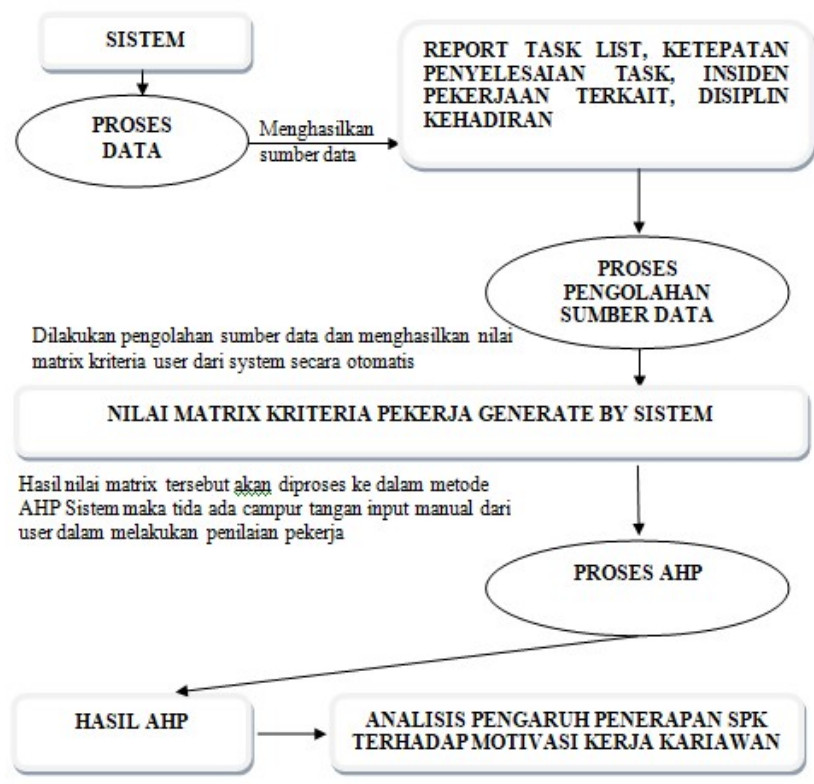

Gambar 7: Gambaran umum

Sesuai Gambar 7. diawali dengan sistem melakukan proses data untuk perhitungan record harian pekerja baik data task, absensi, penilaian manajemen maupun insiden report. Setelah proses generate data selesai lalu data tersebut diolah dan dimasukan ke subkriteria masing masing sesuai dengan kriteria yang sudah ditentukan. Pada proses AHP dilakukan proses data kriteria dengan metode AHP dimana data record pekerja tersebut diolah dengan metode AHP. Setelah hasil dari proses AHP keluar maka manajemen dapat mengakses hasil proses AHP tersebut untuk melakukan pengambilan keputusan sesuai hasil AHP. Pada tahap terakhir setelah sebulan penggunaan sistem maka dilakukan analisis dampak penerapanya oleh peneliti. Pada tahap ini peneliti melakukan melakukan survey dengan 5 skala likert dan diolah dengan metode Multiple Linear Regression Analysis dimana akan berfokus pada analisis pengaruh penerapan sistem dan transparansi nilai kinerja

$$
\text { p-ISSN:1693 - 2951; e-ISSN: 2503-2372 }
$$


pekerja terhadap motivasi kerja. Peningkatan dalam pengerjaan task adalah goal utama pihak manajemen dimana sistem ini diharapkan akan mampu meningkatkan kecepatan pekerja dalam mengerjakan suatu task.

\section{KESIMPULAN}

Dari semua pembahasan dapat penulis simpulkan kaitanya terhadap penelitian yang sedang dilakukan oleh penulis dimana sebuah Decision Support System (DSS) dengan menerapkan metode Analytical Hierarchy Process (AHP) yang dapat menganalisa dalam pemilihan pegawai yang memiliki prestasi. SPK membantu dalam melakukan penilaian para pegawai, memberi penilaian kriteria, serta menilai bobot. Penggunaan DSS dalam berbagai bidang telah banyak membantu dalam pengambilan keputusan serta dapat mempercepat suatu proses. AHP membantu dalam pengambilan keputusan secara efektif oleh masalah kompleks dimana AHP memperingkas proses dalam pengambilan keputusan dan memecahkan masalah ke tiap bagiannya, menata setiap variable lalu mensintesis berbagai pertimbangan agar dapat memberi pengaruh terhadap hasil pada keadaan tersebut. AHP nantinya akan membantu dalam memberikan nilai standar dengan memberikan bobot kriteria dimana bobot akan dipergunakan memberi nilai karyawan yang layak direkomendasikan kontrak kerja nantinya. Analisis dilakukan setelah penerapan sistem AHP. Metode Analisis dampak dengan metode Multiple Linear Regression untuk menilai efektivitas penggunaan sistem terhadap motivasi pekerja perusahaan. Penelitian ini mendapatkan hasil evaluasi pengembangan sistem DSS dengan metode AHP berbasis dekstop menjadi paling dominan dengan angka 58\% dimana pada project pemerintahan menjadi yang terbanyak $48 \%$.

\section{REFERENSI}

[1] S. Maharsi, "Pengaruh Perkembangan Teknologi Informasi terhadap Bidang Akuntansi Manajemen," Jurnal Akuntansi dan Keuangan, vol. 2, no. 2 , pp. $127-137,2000$.

[2] S. Jumaili, "Kepercayaan Terhadap Teknologi Sistem Informasi Baru dalam Evaluasi Kinerja Individual," Solo:Simposium Nasional Akutansi VIII, 2005.

[3] W. D. Brinckloe and M. T. Coughlin, Managing Organization, Encino, California:Glencoe Press, 1977.

[4] E. Turban, J. E. Aronson, T. Liang, D. Prabantini, Decision Support System and intelligent system, Yogyakarta :Andi, 2005

[5] M. Raymond and G. Schell, Sistem informasi manajemen: studi sistem informasi berbasis komputer jilid II, Jakarta:PT Prenhallindo, 2004

[6] R. H. Sparague, and H. J. Watson, Decision Support Systems: Putting Theory Into Practice, N.J., Englewood Clifts:Prentice Hall, 1993

[7] P.G.W. Keen and S. Morton, Decision Support System and Organizational Perspective, Boston:Addison-Wesley, 1978

[8] T. L. Saaty, "Decision Making with the Analytic Hierarchy Process," Int J., Services Sciences, pp. 83-98, 2008

[9] A. Faisol, M. A. Muslim, and H. Suyono, "Komparasi Fuzzy AHP dengan AHP pada Sistem Pendukung Keputusan Investasi Properti," $J$. EECCIS., vol. 8, no. 2, pp. 123-128, Des. 2014.

[10] R. R. P. Sari and N. Agustina, "Analisa Keputusan Pemilihan Aplikasi Chatting untuk Group pada Pengguna Smartphone Android dengan Metode Analytical Hierarchy Process (AHP)," J. Komput. Dan Informatika., vol. 19, no. 2, pp. 131-141, Sep. 2017.

[11] A. E. Munthafa and H. Mubarok, "Penerapan Metode Analytical Hierarchy Process Dalam Sistem Pendukung Keputusan Penentuan Mahasiswa Berprestasi” J. Siliwangi., vol. 3, no. 2, pp. 192-201, 2017.

[12] D. Romario, F. A. Bachtiar, and N. Y. Setiawan, "Implementasi Sistem Penilaian Kinerja Karyawan Dengan Menggunakan Metode AHPTOPSIS Untuk Rekomendasi Pemilihan Karyawan Tetap," J. Pengemb. Teknol. Inf. dan Ilm. Komput., vol. 3, no. 4, pp. 3866-3873, Apr. 2019.
[13] H. Susilo, T. Syaifuddin, and Yulianeu, "Implementasi Analytical Hierarchy Process (AHP) Dalam Menentukan Alternatif Kriteria Penempatan Karyawan Di CV. Jasindo Semarang," J. of Manag., vol. 3, no. 3, 2017.

[14] N. Sael, T. Hamim, and F. Benabbou, "Implementation of the Analytical Hierarchy Process for Student Profile Analysis," Int. J. of Emerg.Technol. in Learn., vol. 14, no. 15, pp. 78-93, Aug. 2019.

[15] M. R. A. Kaluku and N. Pakaya, "Penerapan Perbandingan Metode AHP-Topsis dan ANP-Topsis Mengukur Kinerja Sumber Daya Manusia Di Gorontalo," Ilkom. J. Ilmiah., vol. 9, no. 2, pp. 124-131, Agu. 2017.

[16] Y. Kusuma, Linawati, and M. Sudarma, "Penentuan Pemanfaatan Aset Tanah Pemerintah Daerah dengan Sistem Informasi Geografis dan Metode Analitycal Hierarchy Process : Studi Kasus Pemprov Bali," Maj. Ilm. Teknol. Elektro., vol. 16, no. 03, pp. 44-49, Des. 2017.

[17] R. Stevanus, R. I. Handayani, and D. A. Kristiyanti, "Sistem Pendukung Keputusan Pemberian Bonus Karyawan Menggunakan Metode AHP pada Rumah Sakit Buah Hati Ciputat," J. PILAR Nusa Mandiri., vol. 14. no. 2, pp. 267-274, Sep. 2018.

[18] M. H. Muzakki, H. Susilo, and S. R. Yuniarto, "Pengaruh Penggunaan Teknologi Informasi terhadap Kinerja Karyawan (Studi Pada Karyawan PT. Telkom Pusat Divisi Regional V Surabaya)," J. Adm. Bis. Univ. Brawijaya., vol. 39, no. 2, pp. 169-175, 2016.

[19] D. R. Sari, A. P. Windarto, D. Hartama, and Solikhun, "Sistem Pendukung Keputusan untuk Rekomendasi Kelulusan Sidang Skripsi Menggunakan Metode AHP-TOPSIS," J. Teknol. dan Sis. Komput., vol. 6, no. 1, pp. 1-6, Jan. 2018.

[20] B. Harpad and Salmon, "Penerapan Metode AHP dan Metode Topsis dalam Sistem Pendukung Keputusan Pemilihan Asisten Laboratorium Komputer pada STMIK Widya Cipta Dharma Samarinda," Sebatik., vol. 19, no. 1, pp. 28-34, Jan. 2018,

[21] Frieyadie, "Metode AHP Sebagai Penunjang Keputusan untuk Penilaian Kinerja Kerja Karyawan SPBU," J. Tech. Nusa Mandiri, vol. 15, no. 1, pp. 63-68, Mar. 2018.

[22] J. Santony, F. Amir, Sumijan, and R. Novita, "Application of AHP Analysis to Increase Employee Career Paths in Decision Support Systems," J.of Phys.: Conf. Ser., vol. 1339, Apr. 2019.

[23] I G. N. W. Partha, P. N. M. Weking, and Y. P. Sudarmojo, "Designing a Decision Support System for the Best Employee Selection Using AHP Method Case Study PT. Z Bali," Int. J. of Eng. and Emerging Tech., vol. 3, pp. 51-66, no. 2, 2018.

[24] Y. T. Hapsari, "Pengukuran Kualitas dan Brand dengan Metode AHP," Industrial Eng. J. of The Univ. of Sarjanawiyata Tamansiswa., vol. 2, no.1, pp. 1-6, Jun. 2018.

[25] N. Agustina, "Sistem Pendukung Keputusan Pemilihan Browser pada Android Menggunakan Metode Analytical Hierarchy Process (AHP)," $J$. Sistem Inf., vol. 3, no. 2, pp. 228-236, 2014.

[26] M. S. Rais, "Sistem Pendukung Keputusan untuk Pemilihan Lokasi Perumahan Menggunakan Analytical Hierarchy Process (AHP)," Riau J. Of Comput. Scien., vol.2, no.2, pp. 59-72, 2016.

[27] S. I. Pebakirang, A. Sutrisno, and J. S. C. Neyland, "Penerapan Metode AHP ( Analytical Hierarchy Process) untuk Pemilihan Supplier Suku Cadang di PLTD Bitung," J.Onl. Poros.Tek.Mesin., vol. 6, no. 1, pp. 3244, 2017.

[28] Y. Prihartono and H. Magdalena, "Penerapan Metode Analytical Hierarchy Process (AHP) Sebagai Pendukung Keputusan dalam Menentukan Internet Service Provider Terbaik di Pangkalpinang," $J$. Sistem Inf. dan Komput., vol. 5, no. 1, pp. 21-32, Mar. 2016.

[29] B. M. I. Pangestu, and S. N. Anwar, "Pemodelan Sistem Pendukung Keputusan Pemberian Kredit dengan Metode AHP Berbasis Web Mobile," in Proc. SENDI U, Agu. 2018.

[30] M. Widyastuti, A. Wanto, D. Hartama, and E. Purwanto, "Rekomendasi Penjualan Aksesoris Handphone Menggunakan Metode Analitycal Hierarchy Process (AHP), 'J. Konf. Nasional Tek. Inf. dan Komput., vol. 1, no. 1, pp. 27-32, Nov. 2017.

[31] R. R. Valdika, A. L. Nugraha and H. S. Firdaus, "Analisis Ancaman Multi Bencana di Kabupaten Kendal Berbasis Fuzzy Analytical Hierarchy Process," J. Geodesi Undip., vol. 8, no. 1, pp. 133-140, Jan. 2019.

[32] J. G. Ariana, A. Pinandito, and M. T. Furqon, "Rancang Bangun Aplikasi Pengelolaan Bahan Baku Kafe Menggunakan Metode Analytical Hierarchy Process (AHP) dan Push Notification," $J$. Pengemb. Teknol. Inf. dan Ilm. Komput., vol. 2, no. 12, pp. 7271-7277, 2018. 
[33] W. Novitasari and N. Khotimah, "Dampak penggunaan Gadget terhadap Interksi Sosial Anak Usia 5-6 Tahun," Paud Teratai., vol. 5, no. 3, Apr. 2016.

[34] M. K. Kelviandy, "Analisis Pengambilan Keputusaan Menggunakan Metode Analytical Hierarchy Process dalam Menetapkan Sistem Operasi Smartphone yang Tepat Menurut Tingkat Aktivitas Penggunanya didalam Masyarakat," J. Ilm. Inf. Komput., vol. 19, no. 3, pp 54-64, 2014.

[35] A.Siswanto and S. Alim, "Sistem Pendukung Keputusan untuk Pemberian Beasiswa "Program Jont Degree" Universitas Bhayangkara Surabaya Menggunakan Metode Analytical Hierarchy Process (AHP)," Nusantara J. of Comput. and Its Appl., vol. 3, no. 1, pp. 25-36, Nov. 2018.

[36] L. L. Hutabarat, "Pengaruh Pengawasan, Budaya Organisasi dan Remunerasi terhadap Motivasi Kerja Pegawai," J. Ilmiah Mag. Manaj., vol 2, no. 2, pp. 200-213, Sep. 2019.

[37] R. I. Desanti, C. F. Supit, and A. E. Widjaja, "Aplikasi Perekrutan dan Penilaian Karyawan Berbasis Web pada PT. XYZ," J. Ilm. Sistem Inf., vol. 8, no. 2, 2017.

[38] P. K. Putri, I. Mahendra, "Implementasi Metode Analytical Hierarchy Process (AHP) dalam Sistem Pendukung Keputusan Pembelian Rumah di Kota Tangerang," J. Teknoinfo., vol. 13, no. 1, pp. 36-40, 2019.

[39] G. Brahupadhya, L. Jasa, "Penerapan Metode Analytical Hierarchy Process pada Rekomendasi Keputusan Pemilihan SIM Card Provider," Maj. Ilm. Teknol. Elektro., vol. 17, no. 3, pp. 307-310, Des. 2018.

[40] S. Khoirina, "Pengaruh Sistem Pengukuran Kinerja dan Kejelasan Peran terhadap Kinerja Karyawan," J. Akuntan. dan Keuangan., vol. 4, no. 2, Sept. 2013. 
\{Halaman ini sengaja dikosongkan\} 